\title{
Pemodelan Sistem Pengolahan Air Limbah Aktivasi Bentonit
}

\author{
Imron Ramdhani Achmad ${ }^{1 *)}$, Mohammad Yani $^{2)}$, Suprihatin ${ }^{3)}$, Wonny Ahmad Ridwan ${ }^{4)}$ \\ ${ }^{1,4)}$ Program Studi Pengelolaan Sumber Daya Alam dan Lingkungan, Pascasarjana, IPB \\ ${ }^{2,3}$ Program Studi Teknologi Industri Pertanian, Fakultas Teknologi Pertanian, IPB. \\ *email: imr_aja@yahoo.com
}

Received: 11/09/2018; Revised: 15/11/2018; Accepted: 16/11/2018

\begin{abstract}
Abstrak
Ca-bentonit adalah jenis bentonit dengan sifat penyerapan yang baik. Sifat tersebut dapat ditingkatkan dengan mengaktifkannya melalui penambahan asam, tetapi asam apapun yang dipilih memiliki potensi untuk mencemari lingkungan. Penelitian ini mengkaji pengelolaan air limbah bentonit dengan $98 \%$ $\mathrm{H}_{2} \mathrm{SO}_{4}$ sebagai aktivator. Karena produksi yang besar, berkelanjutan dan metode trial and error dalam mencari solusi akan membutuhkan waktu yang lama, diusulkan pemodelan sistem dinamik. Pemodelan menggunakan software Powersim Studio 7 mengacu pada data konsentrasi $\mathrm{H}^{+}$dan jumlah bahan penetral. Model simulasi menghasilkan ilustrasi bahwa pengolahan air limbah yang efektif dan efisien adalah mengganti metode pengenceran air limbah menjadi $126 \mathrm{~m}^{3} / 3$ ton bentonit dan penambahan campuran $\mathrm{NaOH}-k a p u r$ yang diatur secara bertahap. Netralisasi optimum didapatkan pada penambahan 961,9 $\mathrm{kg} \mathrm{NaOH}$ untuk meningkatkan $\mathrm{pH}$ air limbah hingga $\mathrm{pH} 3$ kemudian diikuti dengan penambahan 40,31 kg kapur hingga $\mathrm{pH}$ 6,5 sehingga perubahan $\mathrm{pH}$ dan waktu pengerjaan tetap terkontrol. Biaya total pengolahan optimum membutuhkan biaya total $\mathrm{Rp} 44.100 .716 / 3$ ton bentonit yang diproses.
\end{abstract}

Kata kunci: air, aktivasi, bentonit, limbah, pemodelan

\begin{abstract}
Ca-bentonite is a type of bentonite with good absorption properties. These properties can be improved by activating through acid addition, but any acid chosen has the potential to pollute the environment. This study examines the management of bentonite wastewater with $98 \% \mathrm{H}_{2} \mathrm{SO}_{4}$ as an activator. Because large, sustainable production and trial and error methods in finding solutions will take a long time, dynamic system modeling is proposed. Modeling using Powersim Studio 7 software refers to data on $\mathrm{H}^{+}$concentration and the amount of neutralizing material. The simulation model illustrates that effective and efficient wastewater treatment is to replace the wastewater dilution method to $126 \mathrm{~m}^{3} / 3$ tons of bentonite and the gradual addition of $\mathrm{NaOH}$-lime mixture. Optimum neutralization was obtained from the addition of $961.9 \mathrm{~kg} \mathrm{NaOH}$ to increase the $\mathrm{pH}$ of wastewater to $\mathrm{pH} 3$ and then followed by adding $40.31 \mathrm{~kg}$ of lime to $\mathrm{pH} 6.5$ so that the change in $\mathrm{pH}$ and processing time remained controlled. The optimum total processing cost requires a total cost of IDR 44.100.716 / 3 tons of processed bentonite.
\end{abstract}

Keywords: activation, bentonite, model, waste, water 


\section{PENDAHULUAN}

Bentonit merupakan sumber daya alam yang melimpah di Indonesia, khususnya jenis Ca-bentonit. Potensi kandungan bentonit yang dilaporkan oleh BPS Provinsi Jawa Barat (2016) bahwa produksi bentonit sejak tahun 2014 mengalami kenaikan dari 103.097,06 ton menjadi 108.251,91 ton pada tahun berikutnya. Karakter yang dimiliki bentonit jenis Ca-bentonit sebagai bahan untuk bleaching minyak kelapa sawit menarik banyak peneliti yaitu mencari cara meningkatkan kemampuan bleaching dengan aktivasi terhadap bentonit mentah. Aktivasi bentonit dapat dilakukan dengan perendaman asam yang dimaksudkan untuk meningkatkan luas permukaan dan memodifikasi struktur bentonit seperti yang dijelaskan pada penelitian Nugrahaningtyas et al. (2016). Konsentrasi asam yang digunakan juga berpengaruh pada hasil akhir. Namun, jenis asam yang digunakan harus diperhatikan karena akan memberikan dampak negatif bagi lingkungan.

Perusahaan pengolah bentonit mentah di Leuwiliang sampai saat ini menggunakan asam sulfat pekat sebagai aktivatornya. Setelah air limbah hasil proses diolah, air limbah yang dikeluarkan tersebut harus memenuhi syarat di bawah nilai baku mutu, salah satunya adalah nilai $\mathrm{pH}$ antara 6-8. Proses yang dilakukan pada pengolahan air limbah sampai didapatkan kondisi di bawah baku mutu masih belum efektif dan efisien. Metode pengenceran yang dilakukan dan penggunaan bahan penetral masih perlu diperbaiki. Kapasitas air yang dipakai pada proses pengolahan air limbah aktivasi bentonit pada perusahaan ini cukup besar dan tidak mengikuti kaidah pengenceran. Selain itu, pemilihan dan penggunaan bahan penetral harus diperhatikan karena keduanya dapat mempengaruhi hasil akhir proses pengolahan.

Penelitian ini bertujuan untuk (1) mengkaji penggunaan air sebagai metode pengenceran terhadap air limbah agar pengolahan lebih efektif, (2) mengkaji penggunaan bahan penetral yang saat ini digunakan dan (3) membuat pemodelan sistem dinamis pengolahan air limbah aktivasi bentonit dengan penggunaan air yang efisien dan bahan penetral yang efektif. Pemodelan yang dapat disimulasikan adalah cara yang praktis karena dapat digunakan untuk membantu memahami tingkah laku sistem atau mengevaluasi berbagai strategi pengoperasian sistem yang apabila dilakukan kajian tanpa pemodelan akan membutuhkan waktu yang lama.

\section{METODE PENELITIAN}

Penelitian dilakukan di salah satu perusahaan di Kampung Jambu Desa Cibanteng Leuwiliang. Untuk membuat pemodelan pengolahan air limbah membutuhkan data pendukung sebagai dasar pemilihan variabel sehingga dilakukan beberapa pengujian sebagai berikut : (1) pengujian sampel air limbah yang dimaksudkan untuk mengkaji proses pengolahan dan karakter air limbah dilakukan dengan mengambil sampel pada tiap bak proses yaitu bak pengenceran $1-8$ (BE1-BE8) dan bak penetralan (BPA) kemudian mengambil sampel air limbah aktivasi bentonit pada bak pembilasan 1 (BP1), pembilasan 2 (BP2) dan pembilasan 3 (BP3) pada setiap shiftnya selama tiga hari dengan kode sampel $\mathrm{HxSxBx}(\mathrm{H}=$ hari; $\mathrm{S}=$ shift; 
$\mathrm{B}=$ bilasan). Sampel air yang diambil berdasarkan proses pada Gambar 1 .

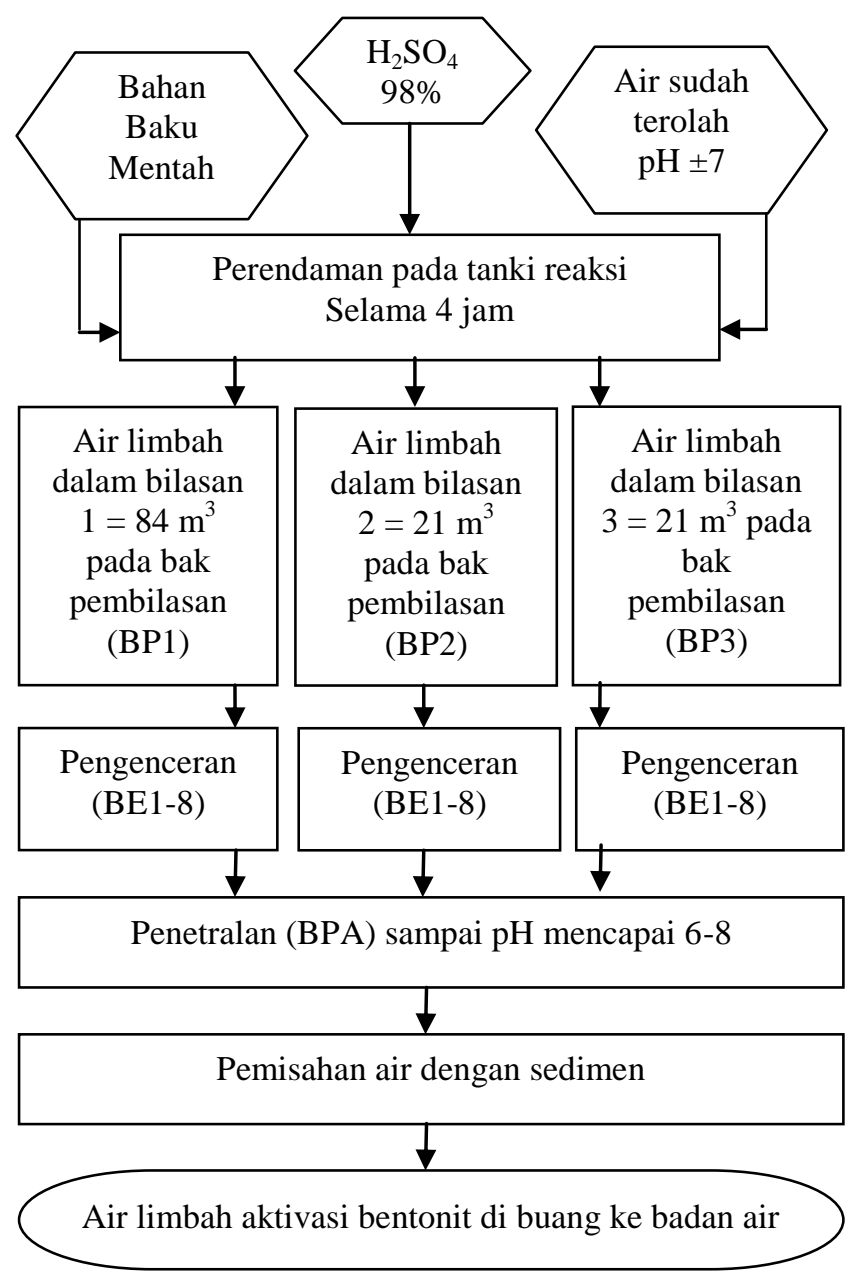

Gambar 1. Proses pengolahan air limbah

(2) pengujian dengan cara titrasi air limbah dengan bahan penetral untuk mengetahui kondisi terbaik dalam pengolahan air limbah sehingga dapat diplot dan disimulasikan. Proses penetralan dilakukan dengan penambahan $\mathrm{NaOH}$ dan kapur dengan ragam variasi molar, (3) identifikasi kadar logam di air limbah dan endapan yang terbentuk. Hal tersebut dilakukan untuk memastikan pengaruh pengolahan terhadap karakter air limbah keterkaitannya dengan baku mutu yang ditetapkan dalam peraturan yang diacu yaitu Permen LHK No. 5 tahun 2014
Lampiran XLVII untuk air limbah dan PP No. 101/2014 Lampiran 5 untuk padatan.

Hasil pengujian dihitung sesuai metode statistika dengan rumus umum standar deviasi sebagai berikut :

$$
\mathrm{S}^{2}=\frac{n \sum_{i=1}^{n} x i^{2}-\left[\sum_{i=1}^{n} x i\right]{ }^{2}}{n(n-1)}
$$

dengan $\mathrm{S}$ adalah simpangan baku dan $x \mathrm{i}$ adalah nilai pH sampel (Hanafiah, 2012).

Proses penstrukturan adalah tahapan penting berikutnya yang merangkai hubungan sebab akibat sehingga menjadi suatu sistem tertutup dan menghasilkan simpal - simpal (loops). Simpal yang bersifat positif mempunyai perilaku percepatan atau perlambatan. Sebaliknya simpal negatif mempunyai perilaku menuju sasaran atas limit. Berdasarkan causal loop yang dibuat kemudian model dirangkai dengan stoikiometri kimia sebagai dasar perhitungan matematika pada model menggunakan Powersim Studio 7.

\section{HASIL DAN PEMBAHASAN}

Proses aktivasi bentonit di Leuwiliang dilakukan dengan memasukkan bentonit mentah berberat jenis antara 2,1 - 2,8 g/mL ke dalam tanki reaksi, kemudian direndam dengan asam sulfat $98 \%$ dan air sungai yang sudah diolah terlebih dahulu sehingga layak pakai. Perbandingan komposisi bahan baku dengan bahan pendukung pada penelitian ini yaitu bentonit mentah : $\mathrm{H}_{2} \mathrm{SO}_{4} 98 \%$ : air $=3$ ton $: 1,2 \mathrm{~m}^{3}: 5 \mathrm{~m}^{3}$. Pengadukan dilakukan selama 4 jam pada suhu ruang sehingga molaritas asam sulfat secara teori terhitung $3,48 \mathrm{M}$. 
Setelah proses aktivasi dianggap selesai, bahan baku mentah yang telah direndam dengan asam sulfat tersebut dibilas dengan air. Bilasan pertama dilakukan dengan membilas bentonit matang dengan $84 \mathrm{~m}^{3}$ air, pembilasan kedua dan ketiga dilakukan dengan volume $21 \mathrm{~m}^{3}$ dan ditampung pada masing-masing bak bilasan. Air bilasan yang ditampung di bak pembilasan (BP) tersebut seringkali masih mengandung bentonit matang yang berukuran kecil yang lolos dari saringan awal sehingga air limbah yang mengandung bentonit matang tersebut harus dibiarkan mengendap terlebih dahulu karena berat jenisnya selama 30 menit. Setelah air dengan endapan terpisah, air limbah aktivasi bentonit tersebut langsung dialirkan ke bak berikutnya yaitu bak pengenceran 1 (BE1) sampai bak pengenceran 8 (BE8) yang berisi air dengan volume keseluruhan $680 \mathrm{~m}^{3}$. Air yang digunakan di setiap bak tersebut tidak selalu diganti setiap ada penambahan aliran air limbah aktivasi bentonit, dengan begitu prinsip pengenceran sebenarnya tidak dilakukan dengan baik.

Pengolahan air limbah yang mengandung asam kuat, sudah umum dinetralkan dengan penambahan basa kuat seperti $\mathrm{NaOH}$ atau basa lemah untuk mengurangi besarnya biaya pengolahan. Pengolahan air limbah aktivasi bentonit sedikit berbeda dengan air limbah mengandung sulfat dari industri lain karena selain mengandung asam, air limbah ini juga mengandung logam ikutan serta bahan organik yang dapat ikut terlarut dalam bentonit mentah. Penetralan pada produksi pematangan bentonit menggunakan $\mathrm{NaOH}$ dan kapur dengan jumlah yang fluktuatif.

$$
\text { Penetralan asam - basa }
$$

merupakan reaksi spontan yang tidak memerlukan waktu lama sehingga secara teknis, waktu yang dibutuhkan sangat tergantung kepada sejauh mana petugas lapangan dapat memperkirakan kandungan $\mathrm{H}^{+}$pada air limbah sehingga untuk mengelola secara baik, petugas harus mempunyai informasi di awal proses yang didapatkan dari pengukuran $\mathrm{pH}$ pada air bilasan. Hasil perubahan $\mathrm{pH}$ setiap bak rata - rata ditampilkan pada Gambar 2.

$$
\text { Grafik pada Gambar } 2
$$
menunjukkan bahwa pengenceran yang dilakukan dengan sejumlah air tidak banyak memberikan efek terhadap kenaikan nilai $\mathrm{pH}$ seperti yang terlihat pada BE1 sampai BE6. Perubahan $\mathrm{pH}$ hanya sekitar 0,2 dengan adanya penambahan air sebanyak $680 \mathrm{~m}^{3}$. Nilai pH akan lebih cepat berubah pada penambahan bahan penetral seperti yang terjadi pada air limbah di bak penetralan (BPA). Logam ikutan yang diukur pada survey awal ini ditunjukkan di Gambar 3.

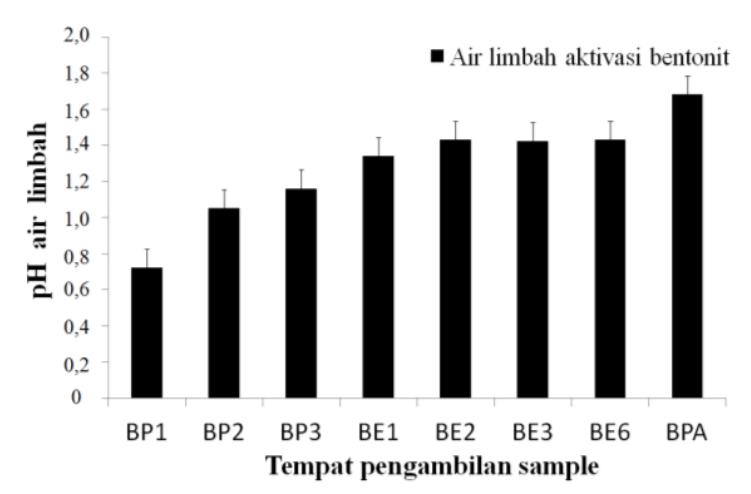

Gambar 2. Perubahan $\mathrm{pH}$ di beberapa bak proses 


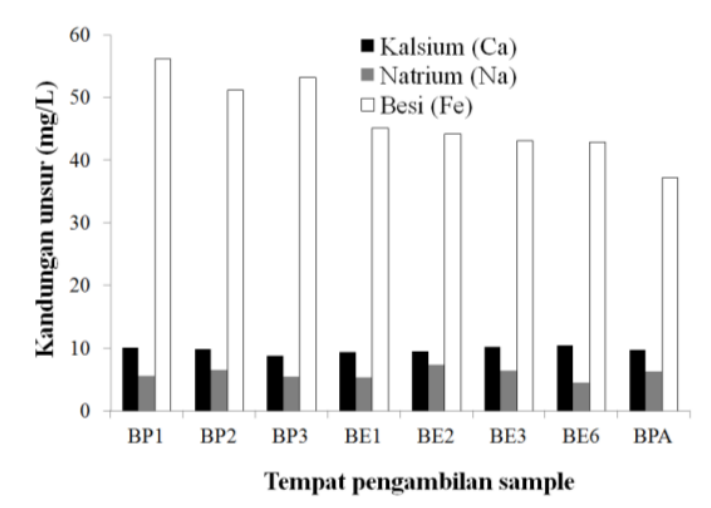

Gambar 3. Kandungan $\mathrm{Ca}$, $\mathrm{Na}$ dan $\mathrm{Fe}$ pada air limbah di tiap bak (diukur dengan AAS)

Hipotesa awal terhadap kondisi ini adalah $\mathrm{H}^{+}$yang terbawa pada bilasan hanya sebagian dari mol $\mathrm{H}^{+}$teoritis yang ada pada larutan. Hal tersebut disebabkan asam sulfat hanya terdisosiasi sebagian. Kandungan Fe pada Gambar 3 mendukung hipotesa pertukaran kation yang terjadi sehingga kandungan $\mathrm{H}^{+}$ berkurang, sekaligus menjelaskan potensi terbentuknya senyawa kompleks dengan sulfat pada air limbah yang terbilas. Kemungkinan lain terjadi sebagaimana penelitian Makhoukhi et al. (2009) yang menyimpulkan bahwa setelah aktivasi akan ada penambahan jumlah asam lemah $\mathrm{Si}-\mathrm{OH}$ di permukaan lempung dan pengaruh aktivasi berdampak besar pada distribusi kekuatan asam dan volume pori-pori. Kondisi tersebut menunjukkan bahwa $\mathrm{H}^{+}$ akan tertahan pada struktur bentonit. Berdasarkan hasil tersebut, dilakukan pengujian untuk mengetahui secara pasti berapa mol $\mathrm{H}^{+}$yang sebenarnya terbawa oleh bilasan pertama, kedua dan ketiga.

\section{Pengukuran pH Sample Tiap Pembilasan}

Pengujian pada bilasan dilakukan untuk mendapatkan gambaran lebih jelas mengenai kondisi yang terjadi pada bak BP1, BP2 dan BP3. Pengujian tersebut menghasilkan nilai yang dirangkum dalam Tabel 1.

Tabel 1. Kandungan mol rata-rata dalam tiap bilasan pada sample uji

\begin{tabular}{cccc}
\hline Bilasan & $\begin{array}{c}\text { Rata } \\
\text {-rata } \\
\text { pH }\end{array}$ & $\begin{array}{c}\text { Standar } \\
\text { Deviasi } \\
\text { pH }\end{array}$ & $\begin{array}{c}\text { Rata-rata Mol } \\
\text { bilasan }\end{array}$ \\
\hline 1 & 0,64 & 0,15 & 20.280 \\
2 & 0,94 & 0,12 & 2.520 \\
3 & 1,20 & 0,13 & 380 \\
\hline
\end{tabular}

Data pada Tabel 1 menunjukkan bahwa kandungan $\mathrm{H}^{+}$yang terbilas pada bilasan satu adalah 20,280 atau 46,94\% dari kandungan mol teoritis $\mathrm{H}^{+}$yang ada pada asam sulfat 3,48 M. Bilasan kedua mengandung $5,83 \%$, dan bilasan ketiga 3,19\%. Nugrahaningtyas et al. (2016) pada penelitiannya menyatakan bahwa proses aktivasi dengan asam $\mathrm{H}_{2} \mathrm{SO}_{4}$ 1,5 $\mathrm{M}$ dapat membuka pori dengan melarutkan kation dalam antar lapis bentonit yang berfungsi sebagai kation penyeimbang seperti $\mathrm{Na}^{+}, \mathrm{Ka}^{+}, \mathrm{Ca}^{2+}$ dan $\mathrm{Fe} 2^{+}$, tapi tidak sampai melarutkan $\mathrm{Al}$, $\mathrm{Fe}, \mathrm{Mg}$ dalam kerangka oktahedral. Semakin tinggi konsentrasi $\mathrm{H}_{2} \mathrm{SO}_{4}$ menyebabkan mineral $\mathrm{Al}, \mathrm{Fe}$, dan $\mathrm{Mg}$ pada lapisan oktahedral larut. Penggunaan aktivasi dengan $\mathrm{H}_{2} \mathrm{SO}_{4}$ berkonsentrasi 3,48 M, menyebabkan pertukaran kation tidak hanya terjadi pada inter layer bentonit tetapi juga pada kisi oktahedral dan peran $\mathrm{H}^{+}$pada pendesakan semakin tinggi. Banyaknya mol yang ikut terbilas dipengaruhi disosisasi, pembentukan asam lemah di permukaan lempung dan pertukaran kation di kisi dan antar kisi yang mana menunjukkan banyaknya mol terbilas secara fluktuatif. 
Data pada Tabel 1 menjadi acuan sebagai koreksi jumlah mol $\mathrm{H}^{+}$yang terbilas yang dapat diplot dalam laju penambahan jumlah mol akibat bilasan. Hipotesa mengenai sebab berkurangnya konsentrasi mol $\mathrm{H}^{+}$merupakan jawaban logis yang mendukung data koreksi jumlah mol $\mathrm{H}^{+}$dapat digunakan pada pemodelan.

\section{Penetralan}

Tahap kedua penelitian yaitu melakukan penetralan skala laboratorium bertujuan untuk melihat karakter air limbah dan mewakili proses yang terjadi di lapangan dengan lebih mudah dan terukur.

Pada penetralan, sampel air limbah ditambahkan larutan $\mathrm{NaOH}$ teknis yang dibuat dari 80 gram $\mathrm{NaOH}$ padat yang dilarutkan ke dalam 1 liter air. Konsentrasi terhitung adalah 0,002 Molar, pH terhitung adalah 11,3 dan $\mathrm{pH}$ terukur adalah $\mathrm{pH}$ 11,53. Titrasi berlangsung sampai terlihat endapan jingga yang terbentuk pada saat penambahan $110 \mathrm{ml}$ larutan $\mathrm{NaOH}$ dan terukur pH larutan adalah 2,28. Endapan jingga ini masih akan menghilang apabila diaduk. Penambahan dilanjutkan sampai volume $\mathrm{NaOH} 160 \mathrm{ml}$, hal tersebut berakibat pada pembentukkan endapan tidak timbul hilang lagi dan mengendap di bawah. Setelah kondisi tersebut, penambahan larutan $\mathrm{NaOH}$ dihentikan. Percobaan berikutnya adalah ditambahkannya larutan kapur yang dibuat dengan melarutkan 400 gram air kapur ke dalam 1 liter. Larutan tersebut digunakan untuk melanjutkan titrasi setelah terjadinya endapan dan dibutuhkan $250 \mathrm{ml}$ air mengandung kapur sampai $\mathrm{pH}$ air menjadi 6,49. Hasil titrasi memberikan rendemen 265 gram. Percobaan titrasi dilakukan dengan berbagai variasi dan kondisi pembentukan endapan jingga yang sama terjadi pada $\mathrm{pH}$ antara 2-4.

Reaksi asam sulfat dengan $\mathrm{NaOH}$ tanpa pengotor semestinya berlangsung sebagai berikut :

$$
\mathrm{H}_{2} \mathrm{SO}_{4}+2 \mathrm{NaOH} \rightarrow \mathrm{Na}_{2} \mathrm{SO}_{4}+2 \mathrm{H}_{2} \mathrm{O} \ldots \text { (2) }
$$

Pada persamaan reaksi tersebut tidak terbentuk endapan dan larutan tidak berwarna (Thompson, 2008). Sampel yang diujikan dengan $\mathrm{CaCO}_{3}$, mengikuti reaksi :

$$
\mathrm{H}_{2} \mathrm{SO}_{4}+\mathrm{CaCO}_{3} \rightarrow \mathrm{CaSO}_{4}+\mathrm{H}_{2} \mathrm{O}+\mathrm{CO}_{2} \ldots \text { (3) }
$$

akan menghasilkan endapan putih CaSO4 (Petkov et al., 2017)

Fakta yang menunjukkan bahwa endapan yang terbentuk berwarna jingga, menunjukkan bahwa persenyawaan akhir yang terjadi tidak sesederhana itu. Endapan bukan hanya natrium sulfat pada persamaan (2) atau kalsium sulfat pada persamaan (3) tapi juga senyawa kompleks logam. Pada penambahan asam sulfat memungkinkan terjadinya reaksi yang mengikuti persamaan reaksi oksidasi sebagai berikut :

$$
\begin{aligned}
1 / 2 \mathrm{O}_{2}+2 \mathrm{H}^{+}+ & 2 \mathrm{Fe}\left(\mathrm{H}_{2} \mathrm{O}\right)_{6}{ }^{2+} \rightarrow \\
& 2 \mathrm{Fe}\left(\mathrm{H}_{2} \mathrm{O}\right)_{6}{ }^{3+}+\mathrm{H}_{2} \mathrm{O} \ldots(4)
\end{aligned}
$$

Dimana $2 \mathrm{Fe}\left(\mathrm{H}_{2} \mathrm{O}\right)_{6}{ }^{3+}$ berwarna kuning, dan pada penambahan $\mathrm{OH}^{-}$ (keadaan basa) pada penetralan akan mengikuti perubahan warna karena reaksi pembentukan kompleks sesuai persamaan (5) (Clark, 2018) :

$$
\begin{aligned}
& \mathrm{Fe}\left(\mathrm{H}_{2} \mathrm{O}\right)_{6}{ }^{3+}+3 \mathrm{NaOH} \\
& \text { kuning } \\
& \quad \underset{\quad}{[}\left[\mathrm{Fe}\left(\mathrm{H}_{2} \mathrm{O}\right)_{3}(\mathrm{OH})_{3}\right]+3 \mathrm{Na}^{+}+3 \mathrm{H}_{2} \mathrm{O} \ldots(5) \\
& \quad \text { jingga }
\end{aligned}
$$


Persamaan lengkap (4) dan (5) digabungkan menjadi persamaan (6) sebagai berikut :

$$
1 / 2 \mathrm{O}_{2}+2 \mathrm{H}^{+}+2 \mathrm{Fe}\left(\mathrm{H}_{2} \mathrm{O}\right)_{6}{ }^{2+}+6 \mathrm{NaOH} \rightarrow
$$$$
2\left[\mathrm{Fe}\left(\mathrm{H}_{2} \mathrm{O}\right)_{3}(\mathrm{OH})_{3}\right]+6 \mathrm{Na}^{+}+7 \mathrm{H}_{2} \mathrm{O} \ldots(6)
$$

Persamaan - persamaan tersebut memperlihatkan pengaruh penambahan asam dan kondisi basa pada saat penetralan.

\section{Kandungan Logam}

Air limbah aktivasi bentonit masih mengandung logam $\mathrm{Fe}, \mathrm{Mn}, \mathrm{Zn}, \mathrm{Co}, \mathrm{Na}$, dan Ca yang sebagian kandungan masih di atas baku mutu yang ditetapkan dalam Peraturan Menteri Lingkungan Hidup nomor 51 tahun 2014 Lampiran XLVII seperti yang terlihat di Gambar 4, oleh karena itu penetralan harus dilakukan selain untuk menurunkan $\mathrm{pH}$ juga mengikat logam menjadi endapan.

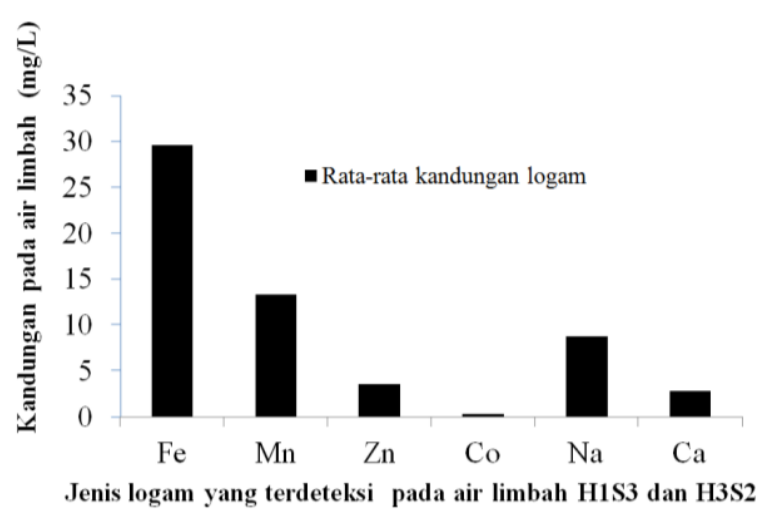

Gambar 4. Kandungan logam ikutan pada dua sampel air limbah

Endapan hasil penetralan diuji kandungan logam beratnya untuk memastikan kategori endapan. Berdasarkan Peraturan Pemerintah nomor 101 tahun 2014 tentang Pengelolaan Limbah Berbahaya dan Beracun Lampiran $\mathrm{V}$ terkait batas total konsentrasi, hasil kandungan logam berat pada endapan yang diukur seperti yang ditunjukkan pada Gambar 5 tergolong sebagai limbah non B3 artinya tidak perlu ada lagi penanganan khusus mengenai limbah endapan dari hasil penetralan. Sedangkan oksida logam yang diukur ditunjukkan pada Gambar 6.

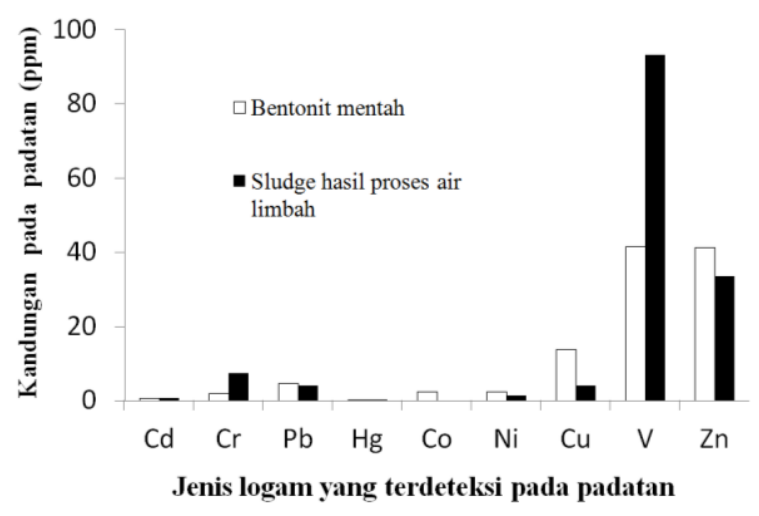

Gambar 5. Kandungan logam ikutan pada endapan hasil penetralan

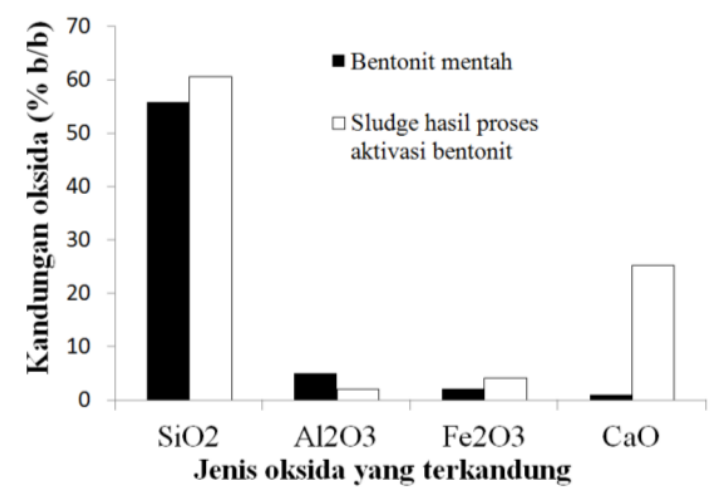

Gambar 6. Kandungan oksida logam dari endapan hasil penetralan

Oksida logam tersebut diukur dengan terlebih dahulu dipanaskan untuk menghilangkan air yang menyelimuti strukturnya.

$$
\begin{array}{r}
{\left[\mathrm{Fe}\left(\mathrm{H}_{2} \mathrm{O}\right)_{3}(\mathrm{OH})_{3}\right] \rightarrow \mathrm{Fe}(\mathrm{OH})_{3}} \\
\rightarrow 1 / 2 \mathrm{Fe}_{2} \mathrm{O}_{3}+3 / 2 \mathrm{H}_{2} \mathrm{O}
\end{array}
$$

Perbandingan air yang sudah dinetralkan dengan baku mutu ditunjukkan pada Tabel 2. 
Tabel 2. Kandungan logam pada air limbah yang buang ke badan air penerima

\begin{tabular}{lrrr}
\hline No. & Parameter & $\begin{array}{c}\text { Baku mutu } \\
(\mathrm{mg} / \mathrm{L}) *\end{array}$ & $\begin{array}{c}\text { Hasil analisa } \\
(\mathrm{mg} / \mathrm{L})\end{array}$ \\
\hline 1 & $\mathrm{Fe}$ & 5 & 2,8 \\
2 & $\mathrm{Mn}$ & 2 & 1,2 \\
3 & $\mathrm{Zn}$ & 5 & 0,3 \\
4 & $\mathrm{Co}$ & 0,4 & 0,03 \\
\hline
\end{tabular}

Catatan :

Mengacu kepada Peraturan Menteri Lingkungan Hidup No. 5/2014 Lampiran XLVII

Hasil yang seperti ditunjukkan pada Gambar 5 menunjukkan bahwa endapan sudah memenuhi syarat kadar logam di bawah baku mutu dan pada Gambar 6 yang merupakan hasil oksida logam menunjukkan bahwa endapan dapat dimanfaatkan sebagai bahan baku dan atau bahan bakar industri semen dimana total oksida harus di atas 50\%. Tentunya pemanfaatan menjadi produk beton lebih menguntungkan perusahaan karena biaya pengeluaran perusahaan dari jasa pengelolaan limbah akan lebih kecil. Efisiensi kinerja proses penetralan dilihat dari perbandingan kandungan logam berdasarkan ekivalen persamaan kimia nya adalah $90,3 \%$.

\section{Pemodelan}

Pemodelan sistem dinamis dimulai dengan identifikasi sistem, yaitu membuat suatu rantai hubungan antara pernyataan dari kebutuhan-kebutuhan dengan pernyataan khusus dari masalah yang harus dipecahkan untuk mencukupi kebutuhan-kebutuhan tersebut yang digambarkan dalam causal loop (Firmansyah et al., 2012). Hasil inventaris dan identifikasi variabel dalam penelitian ini meliputi (1) bahan utama yaitu asam sulfat dan bahan penetral yaitu $\mathrm{NaOH}$ dan kapur, (2) proses yang terjadi terkait proses seperti jumlah mol $\mathrm{H}^{+}$ terukur, netralisasi dan pembentukkan endapan, (3) penggunaan air yang terkait sumber air yaitu air sungai, air yang diolah, air untuk bilasan, dan air cadangan, (4) biaya yang terkait yaitu pembelian bahan baku yaitu asam sulfat, $\mathrm{NaOH}$, kapur, biaya pendukung untuk penggunaan listrik, biaya proses jasa pengurusan endapan dan (5) waktu koreksi. Causal loop pemodelan sistem ditunjukkan pada Gambar 7 menunjukkan dua loop utama yaitu loop penggunaan air dan loop terkait biaya. Pada loop pertama ditunjukkan oleh warna abu tebal dimana loop tersebut merupakan rangkaian [air yang diolah-air bilasanbentonit mentah-mol $\mathrm{H}^{+}$bilasan $(1,2,3)$ mol $\mathrm{H}^{+}$terbilas-air cadangan] dan Pada loop kedua, ditunjukkan ditunjukkan oleh warna hitam tebal dimana loop tersebut merupakan terbentuk dari rangkaian [total biaya-biaya pembelian asam sulfat-asam sulfat-kandungan $\mathrm{H}^{+}$ total-mol $\mathrm{H}^{+}$bilasan $(1,2,3)-\mathrm{mol} \mathrm{H}^{+}$ terbilas-proses netralisasi-biaya proses total endapan]. 


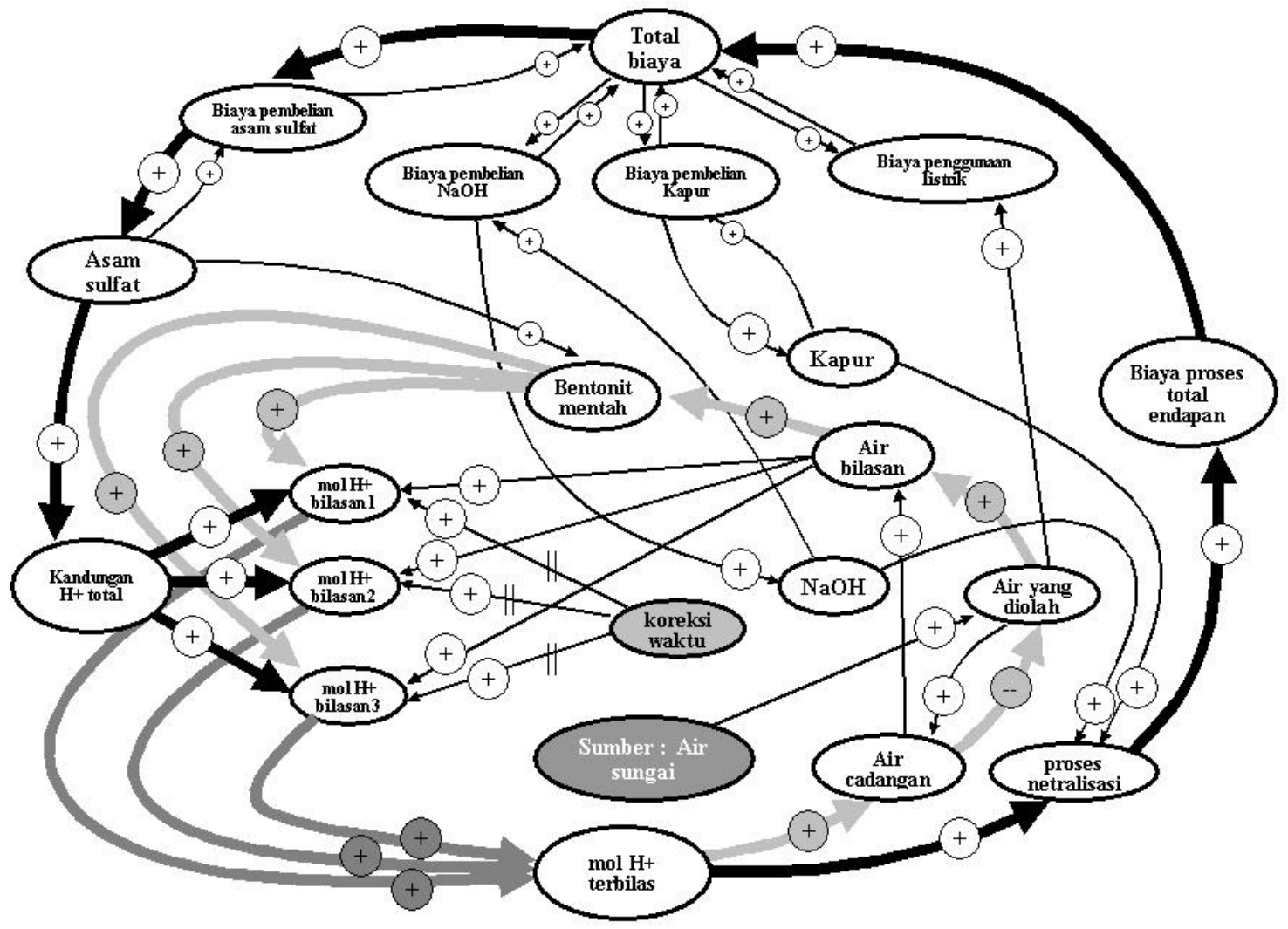

Gambar 7. Causal loop pemodelan pengelolaan air limbah aktivasi bentonit

Ketersediaan air yang diolah akan menambah ketersediaan air yang digunakan untuk bilasan. Ketersediaan air untuk bilasan ini digunakan untuk membawa $\mathrm{H}^{+}$tersisa yang tidak ikut dalam pertukaran kation pada proses aktivasi. Air yang digunakan untuk membilas mempengaruhi seberapa banyak konsentrasi $\mathrm{H}^{+}$yang akan terbawa dalam bilasan, walaupun jumlah mol $\mathrm{H}^{+}$ adalah tetap tetapi konsentrasinya akan berubah. Konsentrasi mol $\mathrm{H}^{+}$-lah yang terbaca sebagai nilai $\mathrm{pH}$ oleh $\mathrm{pH}$ meter. Penggabungan sejumlah mol $\mathrm{H}^{+}$dari bilasan 1, 2 dan 3 menjadi mol $\mathrm{H}^{+}$total yang terproses pada pengolahan air limbah beserta sejumlah volume air.

Air limbah setelah diolah akan menjadi air yang memiliki pH dan kadar logam yang berada di bawah baku mutu dan dinyatakan layak untuk digunakan kembali. Air inilah yang dapat digunakan kembali untuk proses aktivasi selanjutnya. Sejumlah air yang dapat digunakan kembali yang kemudian dinyatakan sebagai air cadangan harus dicek lebih lanjut. Penelitian ini hanya menunjukkan pemodelan yang berhubungan dengan penggunaan air yang dibutuhkan pada proses pengolahan air limbah aktivasi terkait pengenceran dan penetralan.

Air yang sudah melalui tahap penetralan memiliki nilai parameter yang sudah layak digunakan untuk proses pengolahan air pada industri ini. Air yang akan dicadangkan untuk proses tersebut ditentukan oleh cara memisahkan air dan endapan. Cara konvensional dengan menarik air dari bak endapan dalam pemisahan air dan endapan ummumnya meninggalkan $20 \%$ air sehingga air balik yang dapat digunakan adalah pada kisaran $80 \%$, dengan demikian maka penambahan air dari air sungai yang diolah tetap 
diperlukan, hanya saja dalam jumlah yang lebih sedikit daripada kebutuhan air sebelumnya. Apabila pemisahan dilakukan dengan cara yang lebih baik seperti dengan belt press atau pompa vakum, air yang dapat digunakan akan lebih banyak. Tentunya semua hal yang dilakukan sangat bergantung kepada perhitungan dan kegunaan dari proses pengelolaan limbah ini.

Air cadangan pada loop bertanda negatif, artinya dengan adanya air cadangan maka kebutuhan air olahan akan berkurang, penggunaan air dari sungai yang sebelumnya harus diolah terpenuhi dengan adanya air hasil proses pengolahan air limbah. Air cadangan tersebut membatasi penggunaan air sungai sehingga perusahaan dapat memastikan ketersediaan air dari proses yang ada dan aman untuk proses produksinya.

Pada loop kedua, biaya total yang ada dapat dibagi menjadi beberapa kebutuhan yang salah satunya adalah biaya pembelian asam sulfat. Biaya yang tersedia ini akan mempengaruhi berapa banyak asam sulfat yang dapat dibeli sehingga perusahaan dapat mengatur berapa tanki reaksi yang dapat digunakan dan berapa banyak bahan mentah yang dapat diaktivasi. Asam sulfat yang digunakan akan memberikan pengaruh pada berapa banyaknya mol $\mathrm{H}^{+}$ yang akan berproses, sehingga menghasilkan mol $\mathrm{H}^{+}$tertentu pada masing-masing bilasan. Mol $\mathrm{H}+$ yang terbilas kemudian terkumpul sebagai mol $\mathrm{H}^{+}$total yang akan dinetralkan. Efektifitas penetralan yang terjadi akan menambah banyaknya endapan yang terjadi dan hal ini bergantung kepada jumlah $\mathrm{H}^{+}$yang terbawa pada bilasan. Jumlah endapan yang terbentuk ini yang akan mempengaruhi berapa biaya total yang dikeluarkan.

Pemodelan menggunakan aplikasi Powersim Studio 7 didasarkan data mol pada Tabel 1. Pemodelan dibuat dengan menggunakan beberapa konstansta yang dapat dirubah yaitu konstanta untuk menentukan jumlah mol yang akan diproses untuk bilasan 1, bilasan 2 dan bilasan 3 .

Kontanta "Koreksi jumlah mol bilasan" membatasi proses perhitungan dimana tidak semua mol $\mathrm{H}^{+}$yang kemudian terukur sebagai nilai $\mathrm{pH}$ ikut terbilas. Proses berjalan dalam perhitungan "Laju pembilasan" dalam rentang waktu simulasi. Waktu yang digunakan diambil berdasarkan waktu proses selesainya pembilasan. Proses pada model berjalan berdasarkan laju penambahan jumlah mol $\mathrm{H}^{+}$seiring waktu dan berakhir setelah jam simulasi yang ditetapkan tercapai. Pada akhir simulasi akan ditunjukkan jumlah mol total $\mathrm{H}^{+}$. Mol $\mathrm{H}^{+}$harus dinetralkan dengan $\mathrm{NaOH}$ dimana dalam model ini jumlahnya mengacu kepada stokiometri pada persamaan kimia yang ada berdasarkan fakta yang terjadi pada proses titrasi yang dilakukan.

Kondisi dimana endapan terbentuk pada nilai $\mathrm{pH}$ antara 2 sampai 4 menunjukkan bahwa pada posisi tersebut dapat dilakukan variasi penambahan bahan penetral. Pada penelitian ini ditetapkan $\mathrm{pH} 3$ adalah akhir dari penambahan $\mathrm{NaOH}$. Jumlah berat $\mathrm{NaOH}$ yang akan ditambahkan dinyatakan dengan active tool constant yang nilainya dapat dirubah berdasarkan rumus :

$$
\text { Massa }(\text { gram })=\frac{m o l}{M r}
$$


Reaksi dengan karbonat sangat kompleks. Model ini tidak menyatakan variabel suhu dan kekuatan ionik yang juga memiliki pengaruh pada pembentukkan endapan karena penambahan kapur. Penambahan mol Kapur perlu dikoreksi dengan derajat ionisasi kapur berdasarkan penelitian Fusi et al. (2013) yaitu $6,4 \mathrm{~cm}^{3} / \mathrm{mol} . \mathrm{s}$ atau $0,15625 \mathrm{~mol} . \mathrm{s} / \mathrm{mL}$

Terkait hubungannya dengan biaya, model yang dibuat adalah model yang difokuskan pada sistem pengolahan air limbah aktivasi bentonit. Biaya -biaya yang berhubungan dengan pengolahan air limbah adalah biaya pembelian bahan baku dan bahan pendukung, biaya penggunaan air diwakili oleh biaya penggunaan listrik yaitu untuk kebutuhan pompa yang digunakan untuk mengambil air dari Sungai Cikaniki dan biaya listrik dari penggunaan mixer. Kebutuhan biaya listrik didasarkan kepada spesifikasi kerja alat maksimum.

Biaya terkait kebutuhan teknis seperti penggunaan alat yang habis pakai seperti saringan, kertas pengukur $\mathrm{pH}$ universal indicator (bila digunakan), majun dan upah pekerja harian tidak dimasukkan dalam biaya pada pengelolaan air limbah. Biaya-biaya tersebut lebih tepat bila digabungkan dalam pemodelan yang lebih besar lagi yaitu model bisnis perusahaan. Sebagaimana yang ditunjukkan dalam causal loop, pemodelan berkaitan dengan penggunaan biaya dengan asumsi asumsi sebagai berikut :

a. Harga asam sulfat teknis yang dipakai adalah $\mathrm{Rp} 25.000 /$ liter.

b. Harga $\mathrm{NaOH}$ yang dipakai adalah Rp. 13.000/kg c. Harga kapur yang dipakai merupakan kapur dengan rumus $\mathrm{CaCO}_{3}$ dan memiliki derajat disosiasi $0,15625 \mathrm{~mol} . \mathrm{s} / \mathrm{mL}$ dengan harga Rp. 7.000/kg

d. Biaya penggunaan air diasumsikan sebagai biaya pengeluaran listrik dari aktivitas pompa yang memiliki kapasitas 0,25 kWatt. Biaya listrik diasumsikan Rp 1.400/kWh dan penggunaan waktu dihitung berdasarkan simulasi volume air yang digunakan dan waktu simulasi yang dibutuhkan.

e. Biaya proses endapan diasumsikan sebagai biaya yang harus diberikan pada pihak ketiga (transporterpemanfaat) dengan biaya $\mathrm{Rp}$ $1.500 / \mathrm{kg}$.

f. Jumlah endapan yang terjadi didapatkan dari perhitungan stoikiometri berdasarkan mol $\mathrm{NaOH}$ dan mol kapur.

g. Harga bahan pendukung seperti asam sulfat, $\mathrm{NaOH}$, kapur dan pemakaian listrik dianggap sebagai biaya tetap (fixed cost)

h. Jumlah kebutuhan $\mathrm{NaOH}$ dan kapur adalah variable cost dibuat menggunakann active tool konstanta yang dapat disesuaikan.

Harga jasa endapan diasumsikan sebagai variable cost yang dapat berubah dengan menggunakan active tool konstanta, maksudnya bahwa biaya ini sebenarnya dapat ditekan dengan adanya upaya pemanfaatan limbah. Model sistem disiapkan dengan asumsi dan fungsi model pada Tabel 3. Sedangkan Model sistem dinamis berdasarkan causal loop tersebut dapat dilihat pada Gambar 8. 
Tabel 3. Fungsi penting pada model sistem

Koreksi jumlah mol (mengacu pada Tabel 1)
Merupakan koreksi jumlah mol mengacu kepada nilai pH yang terukur.


Imron Ramdhani Achmad*, Mohammad Yani, Suprihatin, Wonny Ahmad Ridwan

Pemodelan Sistem Pengolahan Air Limbah Aktivasi Bentonit

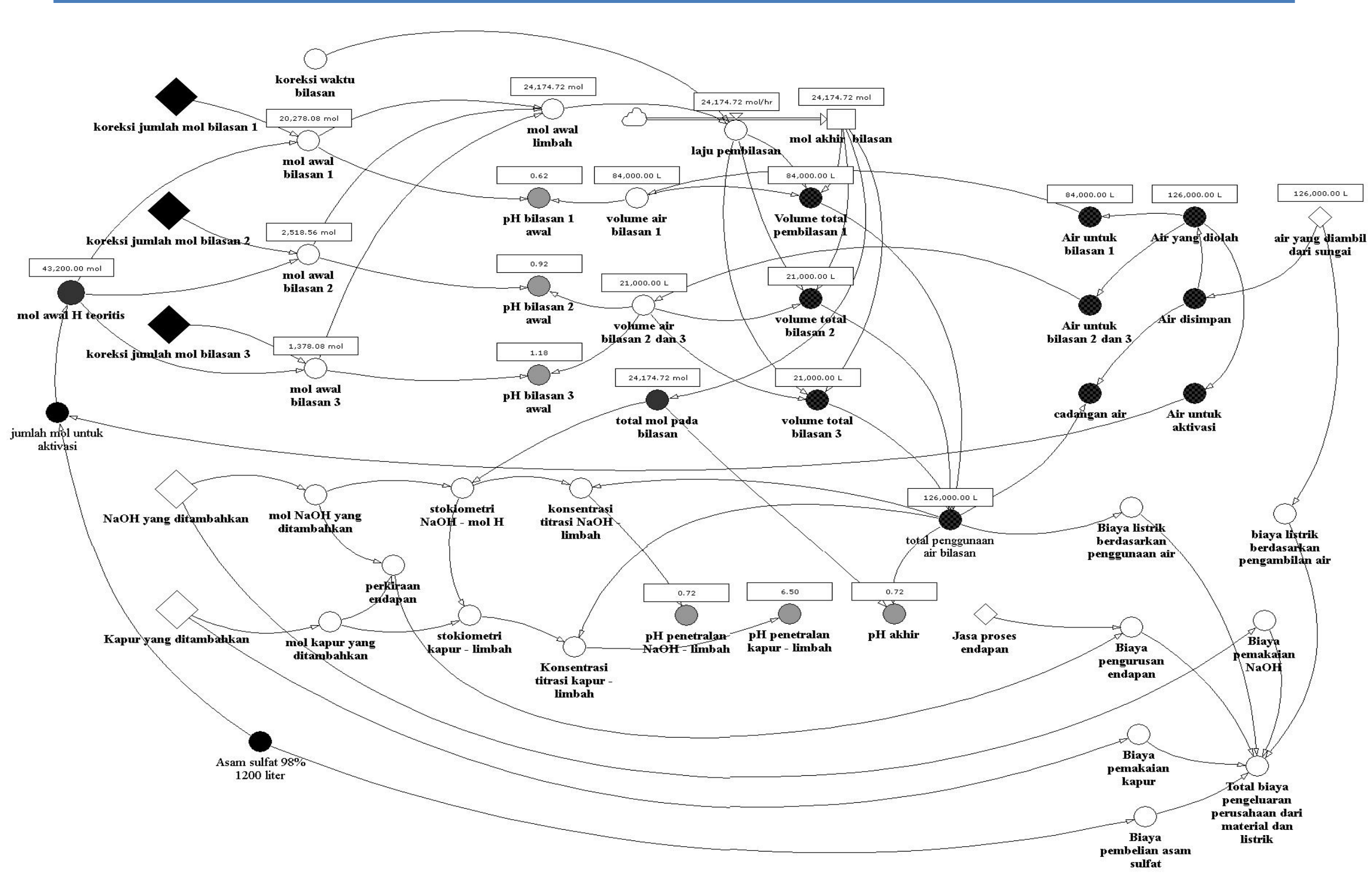

Gambar 8. Model sistem pengelolaan air limbah aktivasi bentonit

CHEESA, Vol. 1 No. 2 Hal 43-57, 2018 | 55 
Model pada Gambar 8 disimulasikan dengan variasi target $\mathrm{pH}$ pada penetralan dengan $\mathrm{NaOH}$ dan didapatkan seperti pada Tabel 4 dan Tabel 5 .

Tabel 4. Simulasi kebutuhan bahan penetral pada model untuk 3 ton bentonit yang diaktivasi

\begin{tabular}{ccrrr}
\hline \multicolumn{3}{c}{ Target pH } & \multicolumn{3}{c}{ Berat yang dibutuhkan $(\mathrm{Kg})$} \\
\hline \multirow{2}{*}{ NaOH } & Kapur & NaOH & Kapur & Endapan \\
\hline- & 6,5 & - & $7.735,89$ & $1.668,05$ \\
1 & 6,5 & 462,99 & $4.031,98$ & $1.280,30$ \\
2 & 6,5 & 916,59 & 403,18 & 900,40 \\
2,5 & 6,5 & 951,05 & 127,49 & 871,58 \\
3 & 6,5 & 961,95 & 40,31 & 862,42 \\
3,5 & 6,5 & 965,39 & 12,73 & 859,53 \\
4 & 6,5 & 966,48 & 4,02 & 858,62 \\
5 & 6,5 & 966,94 & 0,39 & 858,24 \\
6 & - & 966,90 & - & 858,20 \\
\hline Catatan : Total mol H+ pada bilasan adalah \\
$24.174,72$
\end{tabular}

Tabel 5. Simulasi pengeluaran biaya dari variasi penggunaan bahan penetral pada model untuk 3 ton bentonit yang diaktivasi

\begin{tabular}{ccccc}
\hline \multicolumn{2}{c}{ Target pH } & \multicolumn{3}{c}{ Biaya x 1 000 000 (Rp) } \\
\hline NaOH & Kapur & $\begin{array}{c}\text { Penetral- } \\
\text { an }\end{array}$ & $\begin{array}{c}\text { Endap- } \\
\text { an }\end{array}$ & Total \\
\hline- & 6,5 & 54,151 & 2,502 & 86,672 \\
1 & 6,5 & 34,242 & 1,920 & 66,182 \\
2 & 6,5 & 15,123 & 1,350 & 46,493 \\
2,5 & 6,5 & 13,256 & 1,307 & 44,583 \\
3 & 6,5 & 12,787 & 1,293 & 44,100 \\
3,5 & 6,5 & 12,639 & 1,289 & 43,948 \\
4 & 6,5 & 12,564 & 1,287 & 43,899 \\
5 & 6,5 & 12,570 & 1,287 & 43,879 \\
6 & - & 12,570 & 1,287 & 43,877 \\
\hline
\end{tabular}

Catatan : Total mol H+ pada bilasan adalah $24.174,72$

Tabel 4 menunjukkan biaya yang paling rendah adalah jika menggunakan $\mathrm{NaOH}$ saja sebagai bahan penetral, tetapi disepakati disini bahwa peranan kapur berdasarkan hasil titrasi dan stoikiometri yang ada adalah lebih aman menggunakan komposisi penambahan $\mathrm{NaOH}$ sampai $\mathrm{pH} 3$ kemudian dilanjutkan dengan kapur karena selain pada $\mathrm{pH} 3$ tersebut perubahan tidak terlalu signifikan juga perlu disiapkan cara aman untuk melakukan proses yang efektif yang tidak mudah lewat basa. Proses penambahan lewat basa justru akan membuat penggunaan waktu penetralan tidak efektif dan berdampak pada pengeluaran jumlah bahan penetral, pembentukkan endapan dan kebutuhan biaya total secara umum.

\section{KESIMPULAN}

Kesimpulan penelitian mengenai pemodelan pengolahan air limbah didapat bahwa (1) sistem pengolahan air limbah aktivasi bentonit yang efektif adalah sistem pengolahan tanpa adanya pemakaian $680 \mathrm{~m}^{3}$ air untuk proses pengenceran, sehingga proses pengolahan air limbah aktivasi bentonit cukup dengan cara pembilasan dan penetralan. Air bilasan dari masing-masing unit tanki reaksi harus dikumpulkan terlebih dahulu di bak ekualisasi sebelum dilakukan proses penetralan, (2) bahan penetral yang digunakan agar pengolahan air limbah lebih efektif adalah menggunakan penambahan 961,9 $\mathrm{kg} \mathrm{NaOH}$ untuk menaikkan $\mathrm{pH}$ air limbah sampai nilai $\mathrm{pH}$ 3 kemudian dilanjutkan dengan penambahan 40,31 kg kapur sampai $\mathrm{pH}$ 6,5. Penggunaan dua bahan penetral tersebut dimaksudkan untuk lebih dapat mengontrol penggunaan bahan penetral dan menghindari kelebihan basa kuat yang digunakan. Hal tersebut apabila dilakukan dengan baik dapat membantu mengefektifkan waktu proses, mengefisiensikan penggunaan bahan baku dan membuat proses pengolahan menjadi lebih baik. (3) Penggunaan air 
untuk proses aktivasi bentonit dan pengelolaan limbahnya dapat dilakukan dengan menggunakan air sekurangkurangnya $126 \mathrm{~m}^{3}$ air $/ 3$ ton bentonit yang diproses. Air hasil pengolahan limbah dapat disimpan pada salah satu bak penyimpanan dan digunakan kembali untuk proses selanjutnya sehingga dapat mengurangi pengambilan air sungai secara berlebihan. Model sistem dinamis pengolahan air limbah ini diperkirakan membutuhkan biaya total $\mathrm{Rp}$ $44.100 .716 / 3$ ton bentonit yang diproses.

\section{DAFTAR RUJUKAN}

Badan Pusat Statistik. (2016). Provinsi Jawa Barat Dalam Angka. Bandung :BPS Provinsi Jawa Barat.

Clark, J. (2018). Chemistry of Iron. Dilihat 12018. https://chem.libretexts.org/Textbook _Maps/Inorganic_Chemistry/Supple mental_Modules_(Inorganic_Chemi stry)/Descriptive_Chemistry/Elemen ts_Organized_by_Block/3_d-

Block_Elements/Group_08\%3A_Tr ansition_Metals/Chemistry_of_Iron

Firmansyah, I., Riani, E., \& Kurnia, R. (2012). Model pengendalian pencemaran laut untuk meningkatkan daya dukung lingkungan Teluk Jakarta. JPSL, 2(1), 22-28

Fusi, L., Primicerio, M., \& Monti, A. (2013). A model for calcium carbonate neutralization in the presence of armoring. Fiorentina (IT) : Dipartimento di Matematica e informatica, universita degli studi di Firenze - Polo scientific sesto Fiorentino Universitario 50019 sesto Fiorentino.
Hanafiah, K. A. (2012). Rancangan Percobaan - Teori dan Aplikasi, edisi ketiga. Jakarta: Rajawali Pers.

Makhoukhi, B., Didi, M. A., \& Villemin, D., \& Azzouz, A. (2009). Acid activation of bentonite for use as a vegetable oil bleaching agent. Grassas $Y$ Aceites. doi : 10.3989/gya. 108408

Nugrahaningtyas, K. D., Widjonarko, D. M., \& Haryanti, D. Y. (2016). Kajian aktivasi $\mathrm{H}_{2} \mathrm{SO}_{4}$ terhadap proses pemilaran $\mathrm{Al}_{2} \mathrm{O}_{3}$ pada lempung alam Pacitan. Jurnal Penelitian Kimia, 12(2), 190-203

Petkov, K., Stefanova, V., Stamenov, L., Iliev, P. (2017). A study of the partial neutralization process of solutions obtained during autoclave dissolution of pyrite concentrate. Journal of Chemical Technology and Metallurgy, 52(2), 270-276.

Thompson, M. (2008). Sulfuric acid . Dilihat 1 November 2018. http://www.chm.bris.ac.uk/motm/h2 so4/Sulfuric\% 20Acid\%20$\% 20$ Molecule\%20ofthe\%20Month \%20May\%202008.pdf

Titrations.info. (2009). Sulfuric acid titration. dilihat 1 september 2018. http://www.titrations.info/acid-basetitration-sulfuric-acid 